\title{
Research of Universities' Input-Output Efficiency Basing on DEA
}

\author{
LI li \\ (department of management, dalian institute of science and technology, dalian, P.R.china, 116052)
}

\begin{abstract}
According to data envelopment analysis, coupling with the peculiarity of higher school in inputting and outputting, the paper constructs inputting and outputting index system which considered both the teaching and the science research in college and university all-round, and sets up the comprehensive evaluating model for higher school. Then in view of 12 universities' circumstance which subordinate to ministry of education, the paper evaluates their efficiency using frontier analyst soft, and find that the efficiency of the wellknown colleges and universities is not as high as imagination. We should contrast of the output and input to assess university and colleges. Otherwise the result will be unfair. In this way, the universities with higher efficiency will get more resources and be further developed. The universities with lower efficiency should analyze carefully to looking for the way to improve input-output efficiency
\end{abstract}

Keywords: universities; efficiency evaluation; DEA

\section{Introduction}

Education efficiency is ported from the economics. It is the comparison of educational resources inputting and outputting $^{[1]}$. The essence of educational inputoutput allocation is the effective allocation and utilization of educational resources $^{[2]}$. Efficiency evaluation of higher education is a complex system. Under the situation of certain input, the approaches to improve the efficiency is to make full use of existing resources. From the microscopic, the problem of resource allocation and school management can be found by analysis of internal efficiency. This will induce the universities to improve management, develop the potential use of resources, and bring up more higher quality students.

\section{Index System}

When we evaluate the effectiveness of input and output for colleges and universities. The evaluation index system must be able to correctly reflect the basic task of colleges and universities. In this paper, students develop and academic research as two basic tasks are adopted as evaluation criteria. According to scientific principles, system optimization principle, general principles, practical principles and objectives-oriented principles, by analysis of the past evaluation index system, 19 input indexes and 26 output indexes are set at first. Then merger related indicators using cluster analysis to determine the final evaluation index system. ( fig. 1)

By operating the result of Actual indicators value divided by the maximum value of the corresponding index, the different dimensionless input-output indicators are converted into homogeneity evaluation value to describe higher education efficiency. The index value of different 
spacing will be normalized into $[0,1]$ interval $^{[3]}$. Considering the importance of each indicator itself, simultaneously taking full account of raw indictors data variations, each index weight is calculated by using Analytic Hierarchy Process. (fig.2)

\begin{tabular}{|c|c|c|}
\hline & $\begin{array}{c}\text { Level } \\
\text { indicators }\end{array}$ & Secondary indicators \\
\hline \multirow[t]{2}{*}{$\begin{array}{l}\text { Input } \\
\text { Indi- } \\
\text { cat-ors }\end{array}$} & $\begin{array}{c}\text { human } \\
\text { input } \\
\mathrm{X}_{1}\end{array}$ & $\begin{array}{l}\text { 1.Number of teaching teachers } X_{11} \\
\text { 2.Number of research teachers } X_{12} \\
\text { 3. Number of teachers with doctorate } X_{13} \\
\text { 4.Expert number } X_{14} \\
\text { 5.Professor and ph.D number } X_{15} \\
\text { 6.Administrate and support staff number } X_{16}\end{array}$ \\
\hline & $\begin{array}{c}\text { Level } \\
\text { indicators }\end{array}$ & Secondary indicators \\
\hline \multirow[t]{2}{*}{$\begin{array}{l}\text { Input } \\
\text { Indi- } \\
\text { cat-ors }\end{array}$} & $\begin{array}{c}\text { material } \\
\text { resources } \\
\mathrm{X}_{2}\end{array}$ & $\begin{array}{l}\text { 1.Fixed assets } X_{21} \\
\text { 2.Libray holdings } X_{22} \\
\text { 3.Teaching and research equipment worth } \\
X_{23} \\
\text { 4.Number of state key lavoratory and } \\
\text { 5.disciplines } X_{24} \\
\text { 6.Number of research sites } X_{2} \\
\end{array}$ \\
\hline & $\begin{array}{c}\text { financial } \\
\text { invest- } \\
\text { ment } \\
X_{3} \\
\end{array}$ & $\begin{array}{l}\text { 1.government funds } X_{31} \\
\text { 2.tuition } X_{32} \\
\text { 3.other financial income } X_{33}\end{array}$ \\
\hline \multirow[b]{2}{*}{$\begin{array}{l}\text { Output } \\
\text { indicat- } \\
\text { ors }\end{array}$} & $\begin{array}{c}\text { Students } \\
\text { trainning } \\
\mathbf{y}_{1}\end{array}$ & $\begin{array}{l}\text { Training scale } \\
\text { 1.students number } \mathrm{Y}_{11} \\
\text { training quality } \\
\text { 2.number of outstanding doctoral thesis } \mathrm{Y}_{12} \\
\text { 3.number of people getting nationa awards } \\
\text { 4.the ratio of postgraduate getting degree } \mathrm{Y}_{14} \\
\text { 5.employent rate } \mathrm{Y}_{15} \\
\text { 6.number of outstanding teachers } \mathrm{Y}_{16}\end{array}$ \\
\hline & $\begin{array}{c}\text { Academic } \\
\text { and } \\
\text { research } \\
\text { achievem- } \\
\text { ents } \\
y_{2}\end{array}$ & $\begin{array}{l}\text { Academic achievements: } \\
\text { 1.number of scientific papers recorded } \\
\text { by SCI、EI、ISTP } Y_{21} \\
\text { 2.number of social science papers recorded } \\
\text { by SSCI、A \&HHCI、ISSHPY }{ }_{22} \\
\text { 3.number of papers recorded by CSSCI } Y_{23} \\
\text { research achievements: } \\
\text { 4.number of teachers awarded by the highest } \\
\text { national science and technology } Y_{24} \\
\text { 5.number of people getting china's top ten } \\
\text { scientific and technological progress } Y_{25} \\
\text { 6.number of people getting natu- } \\
\text { ral/invention/improement awards } Y_{26} \\
\text { 7.number of authorized patents } Y_{27} \\
\text { 8.number of outstanding research teachers } \\
\end{array}$ \\
\hline
\end{tabular}

Fig.1: Input and output indexes for university

\begin{tabular}{|c|c|c|c|c|c|}
\hline indicator & $\mathrm{X}_{11}$ & $\mathrm{X}_{12}$ & $\mathrm{X}_{13}$ & $\mathrm{X}_{14}$ & $\mathrm{X}_{15}$ \\
\hline weight & 0.347 & 0.347 & 0.050 & 0.144 & 0.084 \\
\hline indicator & $\mathrm{X}_{16}$ & $\mathrm{X}_{21}$ & $\mathrm{X}_{22}$ & $\mathrm{X}_{23}$ & $\mathrm{X}_{24}$ \\
\hline weight & 0.029 & 0.293 & 0.293 & 0.293 & 0.077 \\
\hline indicator & $\mathrm{X}_{25}$ & $\mathrm{X}_{31}$ & $\mathrm{X}_{32}$ & $\mathrm{X}_{33}$ & $\mathrm{Y}_{11}$ \\
\hline weight & 0.043 & 0.460 & 0.221 & 0.319 & 0.067 \\
\hline indicator & $\mathrm{Y}_{12}$ & $\mathrm{Y}_{13}$ & $\mathrm{Y}_{14}$ & $\mathrm{Y}_{15}$ & $\mathrm{Y}_{16}$ \\
\hline weight & 0.133 & 0.133 & 0.266 & 0.357 & 0.044 \\
\hline indicator & $\mathrm{Y}_{21}$ & $\mathrm{Y}_{22}$ & $\mathrm{Y}_{23}$ & $\mathrm{Y}_{24}$ & $\mathrm{Y}_{25}$ \\
\hline weight & 0.195 & 0.195 & 0.070 & 0 & 0.311 \\
\hline indicator & $\mathrm{Y}_{26}$ & $\mathrm{Y}_{27}$ & $\mathrm{Y}_{28}$ & & \\
\hline weight & 0.117 & 0.070 & 0.044 & & \\
\hline
\end{tabular}

Fig.2: The weight distribute of indicator

\section{Model of Data Envelopment Analy- sis}

Suppose there are $\mathrm{n}$ objects to be evaluated, called the decision-making units (DMU). Each DMU has $\mathrm{m}$ inputs and $\mathrm{s}$ types of output. $\mathrm{X}_{\mathrm{ij}}$ means the numbers of $D_{M} U_{i}$ inputting to $j$. $Y_{i k}$ means the numbers of $\mathrm{DMU}_{\mathrm{i}}$ outputting to k. so, $\mathrm{DMU}_{\mathrm{i}}$ input can be expressed as:

$$
\mathrm{X}_{\mathrm{i}}=\left(\mathrm{x}_{\mathrm{i} 1}, \mathrm{x}_{\mathrm{i} 2} \ldots, \mathrm{x}_{\mathrm{im}}\right)^{\mathrm{T}}, \quad(\mathrm{i}=1,2, \ldots, \mathrm{n})
$$

$\mathrm{DMU}_{\mathrm{i}}$ output can be expressed as:

$$
Y_{i}=\left(y_{i 1}, y_{i 2}, \ldots, y_{i s}\right)^{T}, \quad(i=1,2, \ldots n)
$$

$\mathrm{DMU}_{\mathrm{i}}$ efficiency can be expressed as:

$$
\mathrm{E}_{\mathrm{i}}=\frac{\mathrm{u}^{\mathrm{T}} \mathrm{Y}_{\mathrm{i}}}{\mathrm{v}^{\mathrm{T}} \mathrm{X}_{\mathrm{i}}}, \quad(\mathrm{i}=1,2, \ldots \mathrm{n})
$$

If we want to evaluate $\mathrm{DMU}_{0}$, it inputs $\mathrm{X}_{0}$, outputs of $\mathrm{Y}_{0}$. Then the relative efficiency evaluation model of $i_{0}$ DMU is:

$$
\begin{aligned}
& \max E_{0}=\frac{u^{T} Y_{0}}{v^{T} X_{0}} \quad u \geq 0, \quad v \geq 0 \\
& \sum_{i=1}^{s} u_{i}=1, \quad \sum_{i=1}^{m} v_{i}=1 \\
& \frac{u^{T} Y_{i}}{v^{T} X_{i}} \leq 1, \quad i=1,2, \ldots, \quad n
\end{aligned}
$$


Using the Charness-Cooper transformation and dual programming theory, And introducing of slack variables s + , sand Non-Archimedean infinitesimal $^{\mathcal{E}}$,the above model can be transformed into a linear programming model.

$$
\begin{aligned}
& \min \left[\theta-\varepsilon\left(\hat{\mathrm{e}}^{\mathrm{T}} \mathrm{S}^{-}+\mathrm{e}^{\mathrm{T}} \mathrm{S}^{+}\right)\right], \\
& \text {s.t. } \quad \sum_{\mathrm{i}=1}^{\mathrm{n}} \mathrm{X}_{\mathrm{i}} \lambda_{\mathrm{i}}+\mathrm{S}^{-}=\theta \mathrm{X}_{0}, \\
& \sum_{\mathrm{I}=1}^{\mathrm{N}} \mathrm{Y}_{\mathrm{i}} \lambda_{\mathrm{i}}-\mathrm{S}^{+}=\mathrm{Y}_{0}, \\
& \lambda_{\mathrm{i}} \geq 0, \quad \mathrm{i}=1,2, \ldots, \quad \mathrm{n} \\
& \mathrm{S}^{-} \geq 0, \quad \mathrm{~S}^{+} \geq 0
\end{aligned}
$$

Among them, $\varepsilon$ is the NonArchimedean infinitesimal, $\hat{\mathrm{e}}=(1,1, \ldots .1) \in \mathrm{E}_{\mathrm{m}}$, $\mathrm{e}^{\mathrm{T}}=(1,1, \ldots, 1) \in \mathrm{E}_{\mathrm{s}} \cdot \mathrm{S}^{-}$is vector corresponding to input, $\mathrm{S}^{-}=\left(\mathrm{S}_{1}^{-}, \mathrm{S}_{2}^{-}, \ldots \mathrm{S}_{\mathrm{m}}^{-}\right)^{\mathrm{T}} . \mathrm{S}^{+}$is the vector corresponding to output, $\mathrm{S}^{+}=\left(\mathrm{S}_{1}^{+}, \mathrm{S}_{2}^{+}, \ldots, \mathrm{S}_{\mathrm{s}}^{+}\right)^{\mathrm{T}}$.

The results and analysis of model parameters:

(1) $\mathrm{DMU}_{0}$ is DEA efficient

When $\theta=1$ and $\mathrm{S}^{-}=\mathrm{S}^{+}=0, \mathrm{DMU}_{0}$ is DEA efficiency. That is among $\mathrm{n}$ evaluation objects, on the basis of input $\mathrm{X}_{0}, \mathrm{Y}_{0}$ achieve the optimal output.

(2) $\mathrm{DMU}_{0}$ is non-efficient of DEA

When $\theta<1, \mathrm{DMU}_{0}$ is DEA nonefficient. That is the $\mathrm{DMU}_{0}$ input can be reduced to $\theta \mathrm{X}_{0}$ as well as original $\mathrm{Y}_{0}$ unchanged.

\section{Empirical Analysis}

\section{1. the Original Data Source}

In this paper, the original input and output data of 12 key universities in 2003 comes from the compilation of basic statistics of ministry of education under
2003, and the university website and related official websites.

\subsection{Evaluation Results of Overall Ef- ficiency}

According to the provision of samples and indicators numbers in DEA evaluation model, the sample size is at least twice the number of indicators ${ }^{[4]}$. Or the sample size is greater or equal to the number of input-output multiplied ${ }^{[5]}$. This index system calculate five-level indicators including of the human input, material resources and financial input, student training, academic research basing on the standardized data of indicators and corresponding weights. The overall efficiency of 12 colleges and universities are calculated using frontier analyst soft as fig.3.

\begin{tabular}{|c|c|c|c|}
\hline university & $\begin{array}{c}\text { Tsinghua } \\
\text { university }\end{array}$ & $\begin{array}{c}\text { Zhejiang } \\
\text { university }\end{array}$ & $\begin{array}{c}\text { Peking } \\
\text { university }\end{array}$ \\
\hline efficiency & 1 & 0.6719 & 0.9572 \\
\hline university & $\begin{array}{c}\text { Shandong } \\
\text { university }\end{array}$ & $\begin{array}{c}\text { Jilin } \\
\text { university } \\
\text { university } \\
\text { of science } \\
\text { and tech- } \\
\text { nology }\end{array}$ \\
\hline university & $\begin{array}{c}\text { nanjing } \\
\text { university }\end{array}$ & $\begin{array}{c}\text { Shanghai } \\
\text { university }\end{array}$ & $\begin{array}{c}\text { Fudan } \\
\text { university }\end{array}$ \\
\hline efficiency & 1 & 0.6493 & 0.6941 \\
\hline university & Tianjin & $\begin{array}{c}\text { xi'an jiao- } \\
\text { tong uni- } \\
\text { university }\end{array}$ & $\begin{array}{c}\text { dalian uni- } \\
\text { versity of } \\
\text { technology }\end{array}$ \\
\hline efficiency & 0.8852 & 1 & 1 \\
\hline
\end{tabular}

Fig.3: university efficiency

\subsection{Evaluation Results}

Overall, the efficiency of the well-known colleges and universities directly under the ministry of education is not as high as the imagination. Of the 12 universities, the efficiency of tsinghua university, nanjing university, xi'an jiaotong university, dalian university of technology is the highest. Among them, tsinghua university and nanjing university are high input, 
high output type, xi'an jiaotong university, dalian university of technology are low input, low output type. Minimum input-output efficiency of jilin university for $39.97 \%$, Shandong university is $58 \%$. Remaining colleges are in the middle position. Of course, this only reflects a relative number. But we can see that it's very important to raising efficiency of resource in current lack of investment.

\section{Results}

Based on past evaluation of university, whether wangda or the guangdong branch of china academy of management, their ranking are very different, mainly because the different evaluation ideas. In their index system, inputs and outputs, together as the elements of university strength $^{[6]}$. In short, the "input+output" value is as the basis of university strength. Thus some college less investment is in the position behind. Such as xi'an jiaotong university and dalian university of technology, their inputs in human, material and financial resource are much less than the inputs of peking university and jilin university. In this article, the "outputs/inputs" value is taken as the basis for evaluation. Evaluation results are certainly different. In addition, in the past university ranking, a large weight is set to the index of students number, so that some university with large number of students rank much earlier. In this paper, the weight of student number is only $6.7 \%$, the student cultivate value is more measure from the quality of students, which is a major cause of the different measurement results.

We should contrast of the output and input to assess university and colleges. Otherwise the result will be unfair. Measuring input-output efficiency will guide the higher education to the correct target of making full use of resources. Especial- ly in present situation that educational investment inadequate and the quality of education needs to be improved, we should evaluate the university development potential based on education efficiency. Then determining how much investment to university according to the university potential. In this way, the universities with higher efficiency of resource use will get more resources and be further developed. The universities with lower efficiency will analyze carefully to looking for the way to improve inputoutput efficiency.

\section{References}

[1] Wang shanmai, "research of education input and output," hebei education publishing house, pp. 188190,2004.

[2] Qu hong、 gao weitao,"data envelopment analysis in evaluation of graduate education input and output," learned journal of beijing university of technology, pp.26-30, 2009.12.

[3] Han dawei, "Management operations research," dalian university of technology publishing house, pp. 499502,2010.

[4] Sheng zhaohan、Zhu qiao、Wu guangmou, "DEA theory methods and applications," science publishing house, pp. 22-41,155,1996.

[5] Soteriou.A.,Zenios,S., " Data Envelopment Analysis: An introduction and an application to bank branch performance assessment," Modern Methods for Business Research, Lawrence Erlbaum Associates,London, pp. 136,1998.

[6] Yan yan, Xu li, "chinese university evaluation index system evolution and problem analysis,"jiangsu higher education, pp. 35-38,2009.1. 